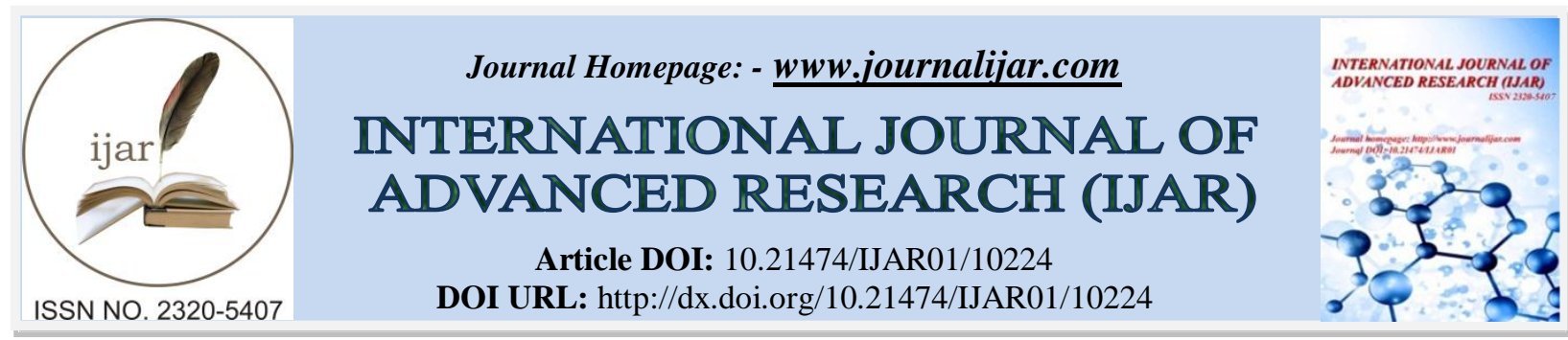

RESEARCH ARTICLE

\title{
THE EFFECT OF SERVANT LEADERSHIP, AFFECTIVE COMMITMENT AND SOCIAL LOAFING ON THE PRODUCTIVITY OF EDUCATIONAL PERSONEL AT BP3IP JAKARTA
}

\author{
Neng Nurwiatin ${ }^{1}$, Matin $^{2}$ and Netti Karnati ${ }^{2}$ \\ 1. Research Scholar, Department of Economics, Thiru.Vi.Ka.Govt. Arts College, Tiruvarur. \\ 2. Assistant Professor, Department Of Economics, Presidency College, Chennai.
}

\section{Manuscript Info}

Manuscript History

Received: 10 October 2019

Final Accepted: 12 November 2019

Published: December 2019

Key words:-

The Effect Of Servant Leadership, Affective Commitment, Social Loafing And Productivity

\begin{abstract}
The purpose is to know the effect of servant leadership, affective commitment and social loafing on lecturer productivity (bp3ip) in Jakarta. This method on this research is Non Experimental Quantitative with study correlation, which is investigating the relationship between two or more variables that aim to test the theory, show the relationship / influence, predict, with the use of statistics. The sample from this research were 92 lecturers in the BP3IP Jakarta environment. The results of this research indicate that; 1) Effect of Servant leadership on Productivity with a path coefficient value of 0.338. 2). Effect of Affective Commitment on Productivity with a path coefficient value of 0.322. 3) Effect of Social Loafing on Productivity with a path coefficient value of $0.281,4)$ Effect of Servant leadership on Social Loafing with path coefficient values of 0.317. 5) Effect of Affective Commitment on Social Loafing with path coefficient value of 0.314 6) Effect of Servant Leadership on Affective Commitment with path coefficient value of 0.418 . Thus an increase in lecturer productivity can be achieved well if there is a strong influence of servant leadership, affective commitment and social loafing influence that is built well.
\end{abstract}

Copy Right, IJAR, 2019,. All rights reserved.

\section{Introduction:-}

Human resources are one element which hasan important role in addition to science and technology in fostering competence globally determined by education. Productivity excellent was the dream of every institution or organization. Organizational productivity is shown through the achievement or work of all elements in accordance with the organization's goals and objectives. The aims of organizational, it can be service improvement, fulfillment of market improvement, improvement of product or service quality, and improvement of competitiveness. Thus the achievement of organizational productivity, it can be is the responsible of every individual and leader in managing organizational resources.

The importance of the role of individual educators in achieving organizational productivity is an asset which it must be maintained and developed. Likewise the role of individuals and groups that will build synergy performance to achieve organizational goals, these roles include the ability, competence, attitude, behavior, commitment and loyalty of educators towards the organization.

Corresponding Author:- Neng Nurwiatin

Address:- Research Scholar, Department of Economics, Thiru.Vi.Ka.Govt. Arts College, Tiruvarur. 
Productivity can be interpreted as the result of work or work performance and how to do it. Armstrong and Baron in Wibowo (2008) explained that performance is the result of work that has a strong influence on the organization's strategic objectives, customer satisfaction, and contributing to the economy.

The higher level of productivity means more outputs are achieved. The elements of productivity are efficiency, effectiveness and quality. Productivity was Output / Input. While the output itself can be the result of the objectives achieved. Inputs are obtained from the resources obtained, for example time, ways to increase productivity namely; increase output, decrease input.

Newstrom (2007) stated the notion of productivity as follows; "Productivity at its simplest, is a ratio that compares units of output with units of input, often against apredetermined standard. If the outputs can be produced from the same amounts of inputs, the productivity has increased. The idea of productivity doesn't imply that one should produce more output; rather, it is a measure of how efficient one produces whatever output is desired. In a simple productivity can beinterpreted that is the ratio thatcompares output units with input units, this ratio is often compared to predetermined standards. If the amount of output can be produced more with the same number of inputs, then productivity can be said to increase. The idea of productivity doesn't mean that a person must produce more quantities of output, but rather a measure of how efficient it is in producing a desired output.

The ability of these performance results is a measurable result of one's experience, commitment and opportunity at work. Therefore, performance is not only related to personal characteristics shown by an educator through the work done. However, performance is interpreted as an individual's success in doing his work, and that success is in accordance with the functions and authorities of his specific work in the form of activities during a certain period of time.

It is easy to get good productivity in accordance with the goals and expectations of the organization. Therefore we need comprehensive understanding and knowledge about the productivity of educators and leaders in an institution or organization. Besides productivity also requires supervision, assessment, scoring or review of human resources in doing their work. Thus the leadership needed to serve (servant Leardship) effective commitment (Effective Commitment) and pleasant organization (Social Loafing) for the achievement of the productivity of educators.

Kinicky and Fugate (2012) explain "servant leadership is serving other over self-interest, servant leaders are less likely to engage in self-serving behaviors that hurt others". servant leadership is leader who serves others more than their interests, the leader who serves, the possibility of reducing his own behavior that can hurt others. Leaders serve the needs of their subordinates, so that in behaving towards subordinates a leader does not hurt the hearts of his subordinates and subordinates can work optimally in achieving organizational goals.

Among them is attention to productivity that influences Servant Leadership leaders who are concerned with the interests of subordinates compared to personal interests, Affective Commitments and. Social Loafing, the tendency of individuals to do a little effort at work, and the ineffectiveness of the utilization of human resources, the low awareness of educators towards understanding the basic tasks and functions (tupoksi) of service and not yet optimal mastery of the development of information technology (IT) as a work support by educators, then other problems related to work facilities and facilities are still inadequate. The existing problem turns out that the supporting facilities and infrastructure available have not been maximally fulfilled.

Fred Luttans (2011) explains, "affective commitment involves the employee's emotional attachment to, identification with, and involvement in the organization. Affective commitment is an emotional attachment attached to an employee in identify and involve himself with the organization.

Those of problems become evidence gaps in the management (managerial) of the organization. The availability of work facilities and facilities can be a factor that can reduce the comfort level of educators in their work. Meanwhile, the demand for achieving organizational targets is a reality that cannot be avoided. Therefore Servant Leadership, Affective Commitment, Social Loafing is very influential on the productivity of the teaching staff of the large education, refreshment and improvement of shipping (Jakarta, BP3IP).

Social loafing is an attitude that doesn't care about activities in the organization, it is indifferent, even if left unchecked like this will interfere with the achievement of organizational goals. John M. Ivancevich / Robert / 
Michael (2014) explains "social loafing is the tendency for individuals to exert less effort in groups than when working individually ". Social Loafing is the tendency for individuals to use less effort in groups rather than working individually. Individuals tend to spend a little effort in organizational activities, such as being lazy, indifferent, lacking competence in carrying out tasks.

Based on the information obtained, the Director of BP3IP Jakarta stated that we have a goal, it was namely: realizing a good organizational system (good governance), it was creating peace and order. The productivity of educators in the Jakarta refresher and refresher education center is not running optimally in accordance with the objectives of the organization (September 2015 Preliminary Survey at BP3IP Jakarta). This is due to the constraints faced by the lack of human resources and other supporting resources such as infrastructure, and financial support which ultimately affects the productivity of educators.

Some of these problems become evidence of gaps in the management (managerial) of the organization. The availability of work facilities and facilities can be a factor that can reduce the comfort level of educators in their work. Meanwhile, the demand for achieving organizational targets is a reality that cannot be avoided. Therefore Servant Leadership, Affective Commitment, Social Loafing is very influential on the productivity of the teaching staff of the large education, refreshment and improvement of shipping (Jakarta, BP3IP).

From the description above it can be stated that the problem of this research is the productivity of the teaching staff. According to the results of the educators' questionnaire that ..... In accordance with the phenomena that exist in the big hall of education, refreshment and improvement of the science of shipping (BP3IP) Jakarta. In which is used to explain productivity.

\section{Research of the Methods:-}

Method of the research is Non Experimental Quantitative with correlation research, which is investigating the relationship between two or more variables that aim to test the theory, show relationships / influence, predict, with the use of affordable population statistics in this research areas many as 120 (one hundred and twenty) educators in the BP3IP Jakarta. Sample size in this research was taken from the sampling frame obtained using the standard error formula with proportionate stratified random sampling. This technique is used if the member of population that are not homogeneous and proportionally stratified. In this research the population was taken as many as 120 teaching staff.

\section{Hypothesis Test:-}

The result was obtained after doing analysis model, it uses as basic when answer hypothesis and make conclusion for this research. It was explained on hypothesis, it can be describes:

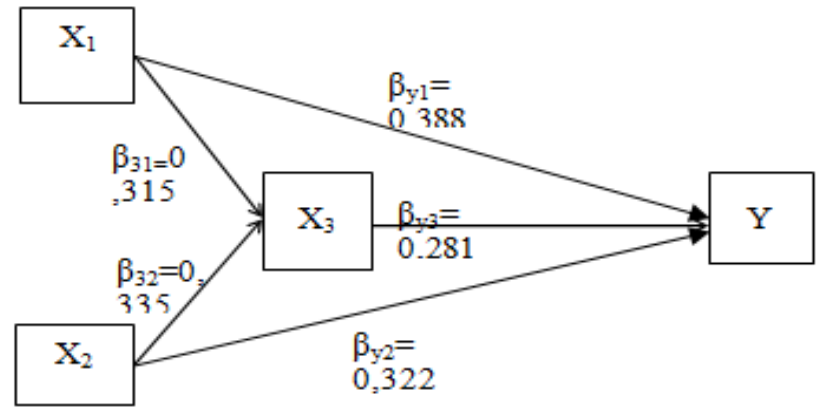

Picture1:- Path Diagram Empiris Structural Model.

An explanation of the path parameter coefficients obtained is as follows:

\section{Research Hypotheses $X_{1}$ to $Y, X_{2}$ to $Y$, and $X_{3}$ to $Y$ :-}

From the results of the calculation path analysis, the servant leadership variable on productivity, the correlation coefficient value of 0.599 , the value of the path coefficient of 0.338 , and the calculated value of 4.09 . Then on the variable affective commitment to productivity, the correlation coefficient can be 0.589 , the path coefficient is 0.322 , and the $t_{\text {count }}$ is 3.90. And on social loafing variables on productivity, the correlation coefficient can be 0.577 , the path coefficient is 0.281 , and the $t_{\text {count }}$ is 3.35 while the value of the table for $\alpha=0.01$ is 2.37 . Because $t_{\text {count }}>t_{\text {table }}$, 
thus $\mathrm{H}_{0}$ is rejected and $\mathrm{H}_{1}$ is accepted, that servant leadership has a direct positive effect on productivity can be accepted, affective commitment has a positive direct effect on acceptable productivity, social loafing has a positive direct effect on acceptable productivity. For more clearly displayed in the following table:

\begin{tabular}{|c|c|c|c|c|c|c|c|c|c|}
\hline \multirow{2}{*}{\multicolumn{3}{|c|}{ Corelation Coefficient }} & \multirow{2}{*}{\multicolumn{3}{|c|}{ Path Coefficient }} & \multirow{3}{*}{$\begin{array}{l}\mathrm{T}_{\text {count }} \\
4,09 * *\end{array}$} & \multirow{2}{*}{\multicolumn{2}{|c|}{$\mathrm{t}_{\text {tabel }}$}} & \multirow{3}{*}{$\begin{array}{l}\text { Conclusion } \\
\text { Very Significant } \\
\end{array}$} \\
\hline & & & & & & & & & \\
\hline $\mathrm{r}_{\mathrm{y} 1}$ & $=$ & 0,599 & $\beta_{\mathrm{y} 1}$ & $=$ & 0,338 & & 1,99 & 2,63 & \\
\hline $\mathrm{r}_{\mathrm{y} 2}$ & $=$ & 0,589 & $\beta_{\mathrm{y} 2}$ & $=$ & 0,322 & $3,90 * *$ & 1,99 & 2,63 & Very Significant \\
\hline$r_{\mathrm{y} 3}$ & $=$ & 0,577 & $\beta_{\mathrm{y} 3}$ & $=$ & 0,281 & $3,35 * *$ & 1,99 & 2,63 & Very Significant \\
\hline
\end{tabular}

Table 1:- Path coefficients.

The Effect of Servant Leadership on Productivity, Affective Commitment on Productivity, and Social Loafing on Productivity Information :

**) The path coefficient is very significant $\left(\mathrm{t}_{\text {count }}>\mathrm{t}_{\text {table }}\right)$ at $\alpha=0.01$.

The results of the analysis hypothesesresearch was provide findings that Servant Leadership has a direct positive effect on Productivity. Affective Commitment has a direct positive effect on Productivity. Also Social Loafing has a direct positive effect on Productivity. Thus it can be concludedthat Productivity is directly affected positively by Servant leadership, Affective Commitment, and Social Loafing. Increased Servant leadership, Affective Commitment, and Social Loafing resulted in increased Productivity.

1. Research Hypothesis $X_{1}$ to $X_{3}$ and $X_{2}$ to $X_{3}$

Servant leadership has a direct positive effect on Social Loafing and Affective Commitment has a positive direct effect on Social Loafing.

From the calculation results of the path analysis, the Servant leadership variable on Social Loafing, the correlation coefficient is 0.480 , the path coefficient is 0.315 , and the $\mathrm{t}_{\text {count }}$ amounted to 2.71. And on the Affective Commitment variable on Social Loafing, the correlation coefficient value is 0.491 ; path coefficient value of 0.335 ; and the $\mathrm{t}$ -

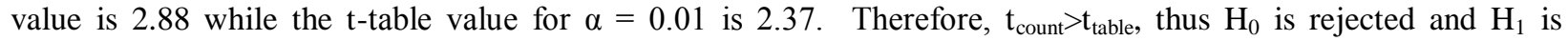
accepted, it was namely that Servant leadership has a direct positive effect on Productivity can be received and Affective Commitment has a positive direct effect on Productivity can be accepted. For more clearly displayed in the following table:

Table 2:- Path Coeffecient.

\begin{tabular}{|l|l|l|l|l|l|l|l|l|l|}
\hline \multicolumn{2}{|l|}{ Correlation Coefficient } & \multicolumn{2}{l|}{ Path Coefficient } & \multicolumn{2}{l|}{$\mathrm{T}_{\text {count }}$} & \multicolumn{2}{l|}{$\mathrm{t}_{\text {table }}$} & Conclusion \\
\cline { 8 - 10 } & & & 0,05 & 0,01 & \\
\hline$r_{31}$ & $=$ & 0,480 & $\beta_{31}$ & $=$ & 0,315 & $2,71 * *$ & 1,66 & 2,37 & Very Significant \\
\hline$r_{32}$ & $=$ & 0,491 & $\beta_{32}$ & $=$ & 0,335 & $2,88^{* *}$ & 1,66 & 2,37 & Very Significant \\
\hline
\end{tabular}

The Effect of Servant Leadership on Productivity, Affective Commitment on Productivity, and Social Loafing on Productivity Information :

**) The path coefficient is very significant ( $\mathrm{t}_{\text {count }}>\mathrm{t}$ table $)$ at $\alpha=0.01$

The results of the fourth hypothesis analysis provide findings that Servant leadership has a direct positive effect on Social Loafing and Affective Commitment has a positive direct effect on Social Loafing. Thus it can be concluded that Social Loafing is directly affected positively by Servant leadership and Affective Commitment is directly affected positively by Affective Commitment. The increase in Servant leadership and Affective Commitment has resulted in increased Social Loafing.

\section{Conclusion:-}

Based on the results of the research data and the results of the analysis of the research data discussed in Chapter 4 with all data analysis requirements including normality test, linearity test and the significance of regression have been fulfilled, then some conclusions can be drawn as follows: 1) Servant Leadership has a direct positive effect on Productivity This means that the accuracy in choosing a good Servant Leadership leads to an increase in the Productivity of BP3IP Jakarta Teachers. 2) Affective Commitment has direct effectpositive towards Productivity, which means an increase in Affective Commitment leads to an increase in the Productivity of BP3IP Jakartateaching 
staff. 3) Social Loafing has a direct positive effect on Productivity, meaning that an increase in Social Loafing causesan increase in the Productivity of BP3IP Jakarta educators. 4) Affective Commitment has a direct positive effect on Social Loafing, meaning that an increase in Affective Commitment causes an increase in Social Loafing for BP3IP Jakarta teaching staff. 5) Servant Leadership has a direct positive effect on Affective Commitment, meaning that the accuracy in choosing Servant Leadership results in an increase in Affective Commitment of BP3IP Jakarta teaching staff.

\section{References:-}

1. Wibowo. (2008). Manajemen Kinerja. Jakarta: PT Raja Grafindo Persada.

2. Newsroom, John W. (2007). Organizational Behavior Firth tenth Edition International Edition of the America. McGraw- Hill Companies, New York.

3. Kinicki and Fugate. (2012). Organizational Behavior Fifth Edition. This International Student is for use outside of the U.S McGraw- Hill Internasioal Edition, New York.

4. Ivancevich, John M. Robert, Michael T. Matteson Konopaske. (2014). Organizational Behavior \& Management. Graw-Hill Internasional Edition (Asia).

5. Luthans, Fred. (2011). Organizational Behavior: An Evidence - Based Approach. New York.

6. International Conference on Africa Development Issues (CU-ICADI) 2015, (diakses tanggal 5 Desember 2018). 